\title{
Cross-border mobility and therapeutic itinerary of Haitians in the Ouanaminthe region
}

Mobilité transfrontalière et itinéraire thérapeutique des Haïtiennes et des

Haitiens de la région de Ouanaminthe

Dominique Mathon, Philippe Apparicio and Ugo Lachapelle

\section{CpenEdition}

Journals

Electronic version

URL: http://journals.openedition.org/rfst/771

DOI: $10.4000 /$ rfst.771

ISSN: 2492-3672

\section{Publisher}

Espaces et SOciétés (UMR 6590)

Electronic reference

Dominique Mathon, Philippe Apparicio and Ugo Lachapelle, "Cross-border mobility and therapeutic itinerary of Haitians in the Ouanaminthe region", Revue francophone sur la santé et les territoires [Online], Varia, Online since 27 September 2019, connection on 06 April 2021. URL: http:// journals.openedition.org/rfst/771 ; DOI: https://doi.org/10.4000/rfst.771

This text was automatically generated on 6 April 2021.

La Revue francophone sur la santé et les territoires est mise à disposition selon les termes de la Licence Creative Commons Attribution - Pas d'Utilisation Commerciale - Partage dans les Mêmes Conditions 4.0 International. 


\title{
Cross-border mobility and therapeutic itinerary of Haitians in the Ouanaminthe region
}

\author{
Mobilité transfrontalière et itinéraire thérapeutique des Haïtiennes et des \\ Haïtiens de la région de Ouanaminthe
}

Dominique Mathon, Philippe Apparicio and Ugo Lachapelle

\section{Background}

1 On 16 September 2017, 40 Haitian, including 15 pregnant Haitian women, were arrested at the Dominican border and repatriated. This information relayed by the Haitian press echoes those published by some Dominican newspapers, which repeatedly denounce the care provided by Dominican public hospitals to Haitian patients and its impact on the health care system. Nevertheless, very few studies in Haiti or the Dominican Republic have addressed this issue even though several authors have pointed out the existence of health care related cross-border mobility. Moreover, the reasons for such mobility are rarely analyzed. For some, the lack of services in Haiti and free access to health care in the Dominican Republic are identified as the main drivers for such behavior. Yet crossing the border (even at official entry points) is not always easy for Haitians. Our paper asks: what then are the driving factors that lead to cross-border health care seeking? At what point in the therapeutic itinerary is such a decision made?

2 Evidence from studies on transnational health related mobility indicates that availability, affordability, accessibility, familiarity and perception of service quality play a role in the decision-making. Furthermore, in a context of proximity with the border, attractiveness of care can polarize the flows in a push/pull dynamics. Several studies also highlight the importance of social networks and ethnolinguistic factors in the decision to travel or return to their country of origin after care has been sought. Dissatisfaction with local services and hope for better care are also among the 
identified driving factors. This lead to complex and sinuous therapeutic paths within and outside one's country.

The main purpose of this paper is to explore the rationale behind the health-related cross-border mobility of Haitians living in or near the border town of Ouanaminthe, Haiti. The driving factors will also be identified and cross-border health utilization will be contextualized within the overall therapeutic itinerary.

\section{Methods}

4 This descriptive qualitative study used several combined methods, namely observation and semi-directive interviews. Overall, 28 interviews were carried out (21 patients, 7 Dominican and Haitian clinicians or decision makers). The interviews with cross-border patients focused mainly on their therapeutic itinerary, the motives behind this decision, obstacles encountered and their perceptions of the quality of care received both in Haiti and the Dominican Republic. Interviews with the clinicians and decision makers helped gathered information on health care facilities, their attendance by Haitian clients and the existing collaboration or system of medical referral between Haiti and the Dominican Republic.

5 An iterative thematic analysis process was conducted. First, a pre-coding based and initial thematic categories inspired from the literature was used. From this process, other thematic categories have emerged, pointing to context specific issues.

\section{Findings}

6 Patients' cross-border health seeking is not linear, but rather a back and forth process between two separate health care systems. For some participants, it lasts several years, while for others, it leads to a first visit. The results show that visiting different health care facilities for the same health problem (or evolving symptoms over time) is usual. Having a second opinion is a frequently reported reason (for both patients and clinicians). The study also shows that cross-border health seeking requires participants to mobilize various skills such as familiarity with the health care system, border crossing experience and abilities, and knowledge of the Dominican language. Respondents also emphasized three main issues related to the Haitian health system that led them to cross-border for health care in the Dominican Republic: 1) the search for efficiency and service quality; 2) the poor patient/clinician relationship; 3) excessive waiting times. Furthermore, the importance of social networks and the strategies used to overcome language barrier is striking. Both clinicians and patients implement different strategies to enable appropriate care. Participants also underlined the important financial burden required to seek treatment abroad.

\section{Conclusion}

7 The cross-border health-related mobility practices observed in Ouanaminthe have many similarities with those analyzed in other contexts. Some aspects have been highlighted but need to be deepened to gain a better understanding of the healthseeking behavior as well as the strategies in place to cope with the expenses. An in- 
depth understanding of individual behaviors and strategies can help in the definition of public health policies and the development of a framework for a bilateral cooperation that takes into account cross-border health mobility practices and the thorny issue of migration.

Figure: Therapeutic itinerary

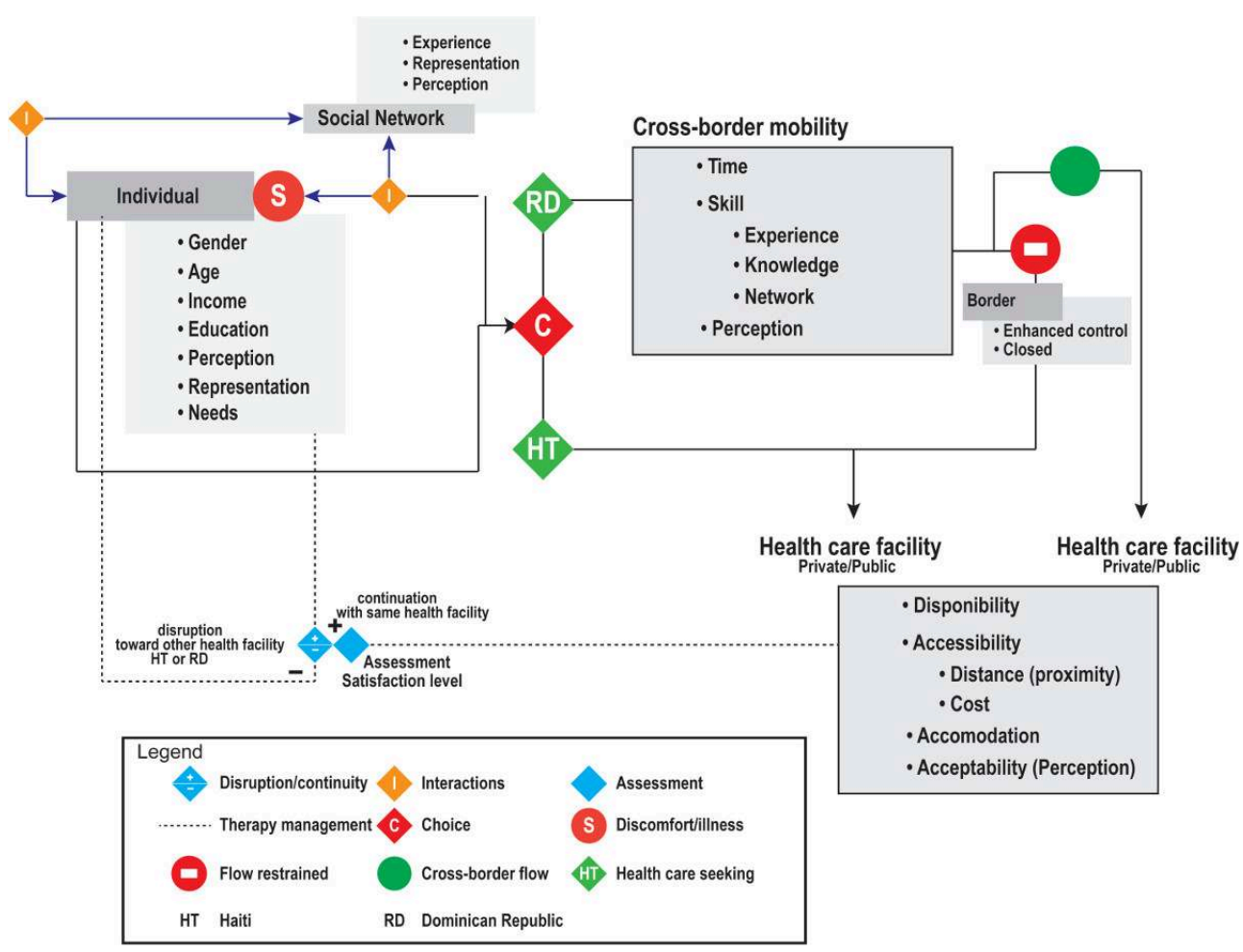

\section{AUTHORS}

\section{DOMINIQUE MATHON}

Laboratoire d'équité environnementale, INRS Centre Urbanisation Culture Société, Canada

\section{PHILIPPE APPARICIO}

Laboratoire d'équité environnementale, INRS Centre Urbanisation Culture Société, Canada

\section{UGO LACHAPELLE}

Université du Québec à Montréal (UQAM), Canada 